\title{
A SURVEY OF THE POLITICAL ECONOMY OF CUSTOMS UNIONS
}

\section{Alain SHEER*}

Nations customarily engage in international trade and just as regularly adopt policies which regulate that trade to meet national objectives. These policies typically involve import (or export) tariffs or their equivalents. Economic integration refers to the process by which nations reduce such trade barriers and reorganize multiple economies to meet national and supranational objectives. The levels of economic integration are usually identified as (1) the free trade area; (2) the customs union; (3) the common market; (4) the economic union; and (5) total economic integration. The free trade area involves the abolition of tariffs and equivalent trade restrictions between members of the area, with each member selecting its own trade policy for nonmembers. The customs union is a free trade area with a common trade policy with respect to nonmembers. The common market has all the elements of the customs union, and additionally, permits factors to move freely among member nations. An economic union is a common market in which members coordinate national economic policies. Finally, total economic integration is an economic union for which a supranational agency determines monetary, fiscal, trade, and social policies for all member nations.

Each integration level involves some elements of freer trade and some of additional protection for producers, "since the protected market available to these producers is enlarged by the creation of a protected position in the markets of other countries partner to the union in addition to their protected position in their domestic market." The "theory of customs unions [is] . . . [a special] branch of tariff theory that deals with the effects of geographically discriminatory changes in trade restrictions"' vey of the fundamentals of international trade theory and of the costs, benefits, and motives for protection by tariff strategy.

\section{I}

\section{Comparative Advantage and the Gains from Trade}

Casual observation demonstrates that consumption decisions by any economic actor result in a diversified consumption bundle and that production may be specialized (i.e., fewer goods are produced than comprise the consumption bundle) or generalized. The advantage of production specialization, whether for an individ-

* The author is assistant professor of Management, Business, Public Policy and Law group, Texas $A \& M$ University. This article is a shortened and less complex version of a monograph on custom union theory commissioned for publication by the Dean Rusk Center, University of Georgia at Athens as part of its comprehensive study of North American Integration and Selective Cooperation. Copies of this materiai are available on request from the Dean Rusk Center.

1. Johnson, The Economic Theory of Customs Unions, Pakistan ECON. J., Mar. 1960, at 14, 15.

2. Lipsey, The Theory of Customs Unions: A General Survey, 70 ECON. J. 496, 496 (1960). 
ual, a region, a nation, or a group of nations, and the process by which such advantage can be realized have been understood since the days of Adam Smith. ${ }^{3}$ Production specialization creates the potential for an enlarged consumption bundle relative to that consistent with generalized production. This potential can be realized only through trade. Specialization in the production of those goods which can be produced relatively efficiently and trading these goods for goods which can only be produced relatively inefficiently reduces the real costs of most, if not all, goods comprising the consumption bundle. ${ }^{4}$ As a result, specialization and trade permit consumption in excess of production capabilities.

It follows that the magnitude of realized gains from trade depends on the terms of trade $^{5}$ at which trade occurs. ${ }^{6}$ The boundaries of the potential range of the terms of trade are the relative prices of these products in each economy in autarchy. This must be so if each trading economy is to gain-or at worst, not losefrom trade. ${ }^{7}$ The actual terms of trade are determined by market forces at the level where the quantity demanded by all traders equals the quantity supplied by all traders. ${ }^{8}$ The result is that free trade between nations depends on the existence of comparative advantages, ${ }^{9}$ and yields real income increases for at least one trading partner without reducing the real income of other traders and of the world as a whole. ${ }^{10}$ There is, simply, a more efficient allocation of the world's productive resources.

This analysis makes clear the necessary preconditions for mutually beneficial trade, as well as the central role of the terms of trade in the allocation of trade gains between trading partners. It follows that any nation which can implement policies affecting the actual terms of trade can alter the magnitude and distribu-

3. See A. Smith, The Wealth of Nations, chs. 1, 2 (1937).

4. This principle, by which the identity of goods to be produced is determined, is termed comparative advantage. The source of the cost or price advantage is unspecified here. In addition to this source of gain from trade, gains may also result from learning by doing (a division of labor and other productive factors) and from economies of scale realized from a larger market. All this presumes that more consumption goods are preferred to fewer consumption goods so that an enlarged consumption bundle adds to consumer welfare. Finally, transportation costs and other impediments are assumed away.

5. "Terms of trade" is defined as the index of the prices of exported products relative to the index of the prices of imported products. Indices are required whenever there are more than one export product and more than one import product.

6. A fuller development of the real income effect is given in note 14 infra.

7. The gain is in the sense of enlarged consumption or real income. The market forces are represented by the balance of trade. Further explanation is provided in note 13 infra.

8. This result involves no assumption about the presence or absence of monopoly or monopsony power.

9. Note that the existence of a comparative advantage implies the existence of a comparative disadvantage so that no single economy can be the most efficient supplier of all products.

10. This discussion does not consider the income redistribution within an economy resulting from trade. The conclusion is merely that the economy as a whole benefits and not that each agent in that economy benefits. Ergo, free trade may be resisted by some segments in an economy. Nevertheless, in principle, it should be possible for the gainers in an economy to compensate the losers in that economy so that free trade benefits all agents in that economy. A caveat which must be recognized is that the appropriateness of any policy depends on the prevailing income distribution. Hence, any policy which changes the income distribution may, in fact, be sounding its own death knell. The usual analysis presumes that the policy produces a relatively small change in the distribution of income so that this difficulty is avoided. For a discussion of the impact of law upon income distribution and Pareto optimality, see Mishan, Pareto Optimality and the Law, 19 OXFORD ECON. PAPERS 255 (1967). 
tion of any international gains from trade. Plainly, this question of political economy (or the exercise of international monopoly or monopsony power) reflects varied interests, including a national desire to increase the gains from trade above the free trade level, and a desire by those losing from a free trade policy to protect themselves from such losses. ${ }^{11}$ The achievement of these objectives is commonly attempted by dumping, cartel, and tariff strategies. ${ }^{12}$

\section{II}

\section{TARIfF Theory AND The Motives for Protection}

\section{A. Tariffs, the Terms of Trade and Real Income ${ }^{13}$}

The tactic usually adopted to exploit price-setting capability is the import good (hereafter import) tariff. The tariff drives a wedge between the relative price of export goods (hereafter exports) on the world market (the terms of trade) and the domestic market. Normally, the imposition of an import tariff improves the terms of trade $^{14}$ available to the imposing nation. ${ }^{15}$ Furthermore, the import tariff

11. Generally, these losers produce goods which can be more efficiently produced or sold by foreigners. Compensation for their losses could eliminate the pressure to exercise monopoly/monopsony power.

12. Tariffs are ad valorem taxes (or subsidies) on imported or exported goods. The Lerner symmetry theorem identifies the economic equivalence of tariffs on imported goods and exported goods. See A. Sheer, The Welfare Costs of Tariffs, Transfers and Exchange Rate Destabilization, at 39-48 (Aug., 1976) (unpublished dissertation in Duke University Library). This consideration of tariffs does not evaluate retaliation effects. For an overview of this problem, see Tower, Sheer \& Baas, Altemative Optimum Tariff Structures as Devices for Transferring Real Income, 45 S. EcON. J. 18 (1978).

13. This discussion does not consider the question of effective protection because the absence of input tariffs has been implicitly assumed. This concept refers to the actual protection afforded by input and output tariff imposition. Simply put, the effect of an input good (or immediate good) tariff is equivalent to a tax on production. This effect works against the effect of an output good tariff, so that domestic import and import-competing production may actually fall relative to the free trade level where input and output tariffs exist simultaneously. As a result, effective protection is a more useful measure of the implications of the tariff structure. See Grubel, A Non-Specialist Guide to the Theory of Effective Protection in EFFECTIVE TARItF PROTECTION 1-4 (H. Grubel and H. Johnson eds. 1971).

14. As is well known, the effect of small changes in the import tariff rate on the terms of trade is described by the equation $-\left(n^{\prime}+\sigma\right) /\left(\epsilon+\epsilon^{*}-1\right)$ when tariffs revenues are returned to consumers or are spent by government in a resource neutral fashion. $n^{\prime}, \sigma, \epsilon$ and $\epsilon^{*}$ represent the imposing nation's compensated price elasticity of demand for imports, that nation's price elasticity of supply of imports or import competing goods, that nation's offer curve elasticity $(\equiv n+\sigma)$ and the foreign nation's offer curve elasticity $\left(\equiv n^{*}+\sigma^{*}\right)$, respectively. The $€$ 's suggest that any price change has three effects: (1) a substitution effect on consumption, (2) an income effect on consumption (where (1) and (2) are given as $n, n^{*}$ ), and (3) a supply effect $\sigma$. $n^{\prime}$ and $\sigma$ are positive, as is $\left(\epsilon+\epsilon^{*}-1\right)$ when the system is stable (i.e., an increase in the import tariff rate reduces (increases) a balance of trade deficit (surplus). Therefore, import tariff imposition should improve (reduce) the imposing nation's terms of trade. However, as Metzler pointed out, this need not be true. See Metzler, "Tariffs, The Terms of Trade, and the Distribution of National Income", 57 J. Pol. Econ. 58 (Feb. 1949).

15. Elasticity measures the relative responsiveness of the quantity demanded (or supplied) to changes in the relative price of the good in question. The price elasticity of demand is another way of expressing the universally adopted result that the quantity demanded varies inversely with product price. The price elasticity of demand may be decomposed into two components: (1) a price substitution term, $n^{\prime} ;$ and (2) an income term, $\mathrm{m}$. The income term simply suggests that a price decline, for example, allows a given money income to purchase a larger quantity of goods and services and therefore is equivalent to some increase in money income, holding prices constant at the original price level. This is plainly welfare-increasing and tends to encourage consumption of all goods (except inferior goods). The substitution effect suggests that consumers respond to the lower relative price by reallocating expenditures in favor of the good whose relative price has fallen while holding the total satisfaction from all consumption constant. As a result, a price decline (increase) creates one force which increases (reduces) the quantity demanded of the good 
usually increases the relative price of imports behind the tariff wall. ${ }^{16}$ Consequently, it is usual for the import tariff to raise the imposing nation's terms of trade and increase the domestic relative price of imports.

These results have opposing effects on real income. Terms of trade improvements are real income increasing because imports cost relatively less on the world market, so that any money income purchases a larger number of consumption good units. However, the increase in the domestic relative price of imports reduces consumption and real income because the domestic relative price of imports exceeds the world price. ${ }^{17}$ The final effect on real income is the sum of these forces. This sum may be positive, negative or zero. ${ }^{18}$ Accordingly, import tariff strategies may, depending on the rate selected, increase, decrease, or have no effect on real income relative to the free trade level. It follows that selection of the tariff rate is crucial to the objective of real income maximization.

The real income maximization (or optimal tariff) argument is but one motive for discrimination. The economics literature provides other motives. These may be generally classified under the headings (1) market failure correction, (2) social welfare objectives, and (3) economic stability objectives. ${ }^{19}$ Discussion of these arguments requires further evaluation of the effects of the import tariff.

The effects of the import tariff within the tariff-imposing nation revolve around the tariff-induced changes in relative prices and tariff revenue considerations. ${ }^{20}$ The increase in the domestic relative price of imports encourages domestic production of imports and import-competing products. The tariff protects these producers from more efficient foreign competition. This process tends to increase the total revenue to producers and the payout to various productive factors. Domestic consumers clearly pay more for import goods and consequently reduce their consumption; they absorb the total cost of tariff revenues unless the nation has the

whose price changed, as well as another force which increases (reduces) the quantity demanded of that good. The net effect of the price change upon the quantity demanded of that good, $n$, is the sum of the income and substitution effects. A formal discussion of these considerations may be found in R. MUNDELL, INTERNATIONAL ECONOMICS 15 (1968). It follows that every absolute price change creates a change in relative prices and a real income effect. As a result, whenever the relative price of exports (the terms of trade) increases (the relative price of imports falls), real income rises.

16. An increase requires that $\left(\epsilon^{*}+m-1\right) /\left(\epsilon^{*} \epsilon^{*}-1\right)$ be positive or that $\epsilon^{*}+m>1$ when the system is stable. $m$ is the tariff-imposing nation's marginal propensity to import (the fraction of each extra income unit devoted to imports).

17. Recall the standard gain from trade involved purchasing at the relatively low price, or selling at the relatively high price, thereby providing a gain relative to the price in autarchy.

Formally, the effect on real income of small import tariff rate changes is given by the sign of the equation -Mdp $+t d M$ where $d p$ is the change in the world relative price of imports due to the tariff rate change (the inverse of the terms of trade effect), $t$ is the tariff rate, $M$ is the free trade volume of imports and $d M$ is the change in the free trade level volume of imports due to the tariff rate change, respectively. Hence, $-\mathrm{Mdp}$ is the terms of trade effect and $t \mathrm{dM}$ is the volume effect.

18. The net effect is positive, negative or zero as the terms of trade effect exceeds, falls short of or equals the volume effect. An example of the net negative result is the prohibitive tariff (which chokes off all trade, producing the autarchy result).

19. This follows the organization adopted by Grubel in H. Grubel, InTERnational Economics, chs. 7,8 (1977).

20. The revenue considerations are considered in note 15 supra and in text accompanying notes 24,25 infra. 
capability to set or affect market price. ${ }^{21}$ The forces generated by the import tariff which bear on these explanations for tariff imposition can be geometrically identified in a partial equilibrium setting. ${ }^{22}$

\section{FIGURE 1}

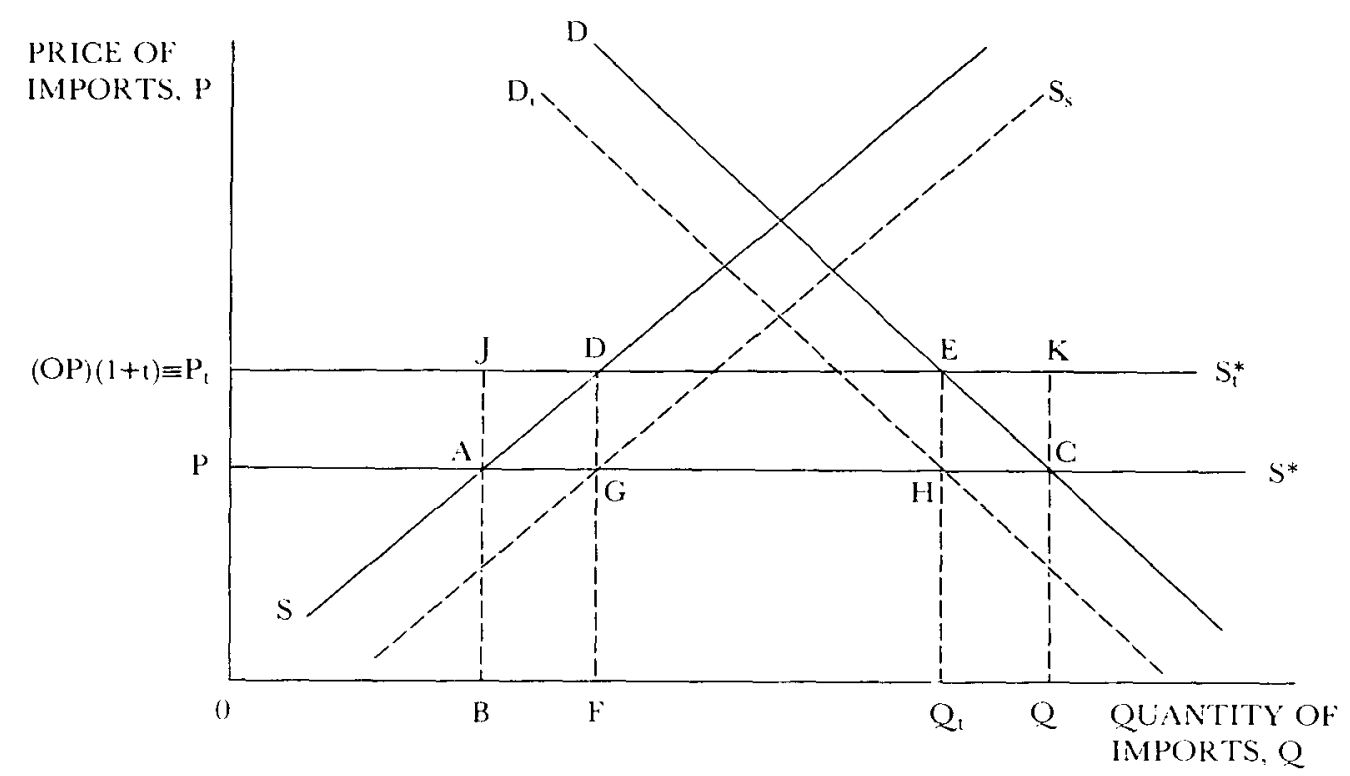

The partial equilibrium analysis usually involves the assumption that the foreign supply function is infinitely elastic (reflecting constant costs). This forces the entire tariff burden onto domestic consumers of imports. In Figure 1, the domestic demand and supply functions are given by the schedules $\mathrm{D}$ and $\mathrm{S}$, respectively, and reflect the usual experience that buyers take less as price rises while sellers offer more under the same conditions. The foreign supply schedule, $\mathrm{S}^{*}$, is horizontal, reflecting constant costs, and intersects the domestic supply schedule at point $A$ (so that domestic suppliers are more efficient at output levels below $O B$ ). Accordingly, the effective supply schedule before tariff imposition is SAS*, with an equilibrium result at point $\mathrm{C}$ (with a price of $O P$ and a quantity supplied and demanded of $O Q)$. The level of domestic production is $O B$ with imports of $B Q$. The tariff falls upon domestic consumers and raises the price of imports to $(\mathrm{OP})(1+\mathrm{t})$ where $\mathrm{t}$ is the tariff rate. This lies above $\mathrm{OP}$ so that the effective foreign

21. The condition required to preclude monopoly/monopsony power is that $\epsilon^{*}=\infty$ so that the tariff has no effect on the terms of trade. This may occur because the foreign price elasticity of demand for the imposing nation's export goods is infinitely elastic (selling more or less cannot affect price) or because the foreign price elasticity of supply of the imposing nation's import good is infinitely elastic (buying more or less cannot affect price). As a result, the tariff burden falls entirely on those consuming import goods in the tariff-imposing nation. R. CaVes \& R. JONES, WORLD Trade AND PAYMents 186-87, $441-44$ (2d ed. 1977).

22. Partial equilibrium means that a single market is the focus for analysis and assumes that changes in price or output in this market have no effective repercussions in other markets. The assumption simplifies the analysis of the effects of tariffs. 
supply schedule becomes $\mathrm{S}^{*}{ }_{\mathrm{t}}$. The effective supply schedule becomes $\mathrm{SADS}^{*}{ }_{\mathrm{t}}$. The market solution yields a price of $\mathrm{OP}_{\mathrm{t}}$ with domestic production of $\mathrm{OF}$ and imports of $F Q_{t}$. Tariff revenues are collected in the amount of $\left(P_{t}-P\right)$ $\left(F Q_{t}\right)=$ GDEH. The summary of effects of the tariff follows:

1. Production effect. Domestic output increases from $O B$ to OF. This output increases producer revenues by $\left(\mathrm{OP}_{\mathrm{t}}\right)(\mathrm{BF})=\mathrm{BJDF}$.

2. Subsidy effect. Domestic producers also receive increased sales revenues on units that would have been produced in the absence of the tariff. This amounts to $\left(\mathrm{P}_{\mathrm{t}}-\mathrm{P}\right)\left(\mathrm{OB}=\mathrm{PP}_{\mathrm{t}} \mathrm{JA}\right.$. The total effect of the tariff on sales revenues is $\mathrm{PP}_{\mathrm{t}} \mathrm{JA}+\mathrm{BJDF}$. However, the area under the supply schedule between any two output levels measures the total variable cost of producing the output difference. These total costs are payments to the productive factors (land, labor, capital, entrepreneurial skill) consumed in producing the output difference so that the tariff increases production costs by the amount BADF. Hence, the net subsidy to producers is the increase in sales revenues less the increase in costs, or PADP . This represents a redistribution of income from consumers to producers.

3. Consumption effect. Consumption of the good falls in the amount $Q Q_{t}$. The area under a demand schedule between two output levels represents what consumers would have been willing to pay to consume that quantity of the product. Here consumers who, prior to tariff imposition, would have been willing to pay $Q_{\mathfrak{t}} \mathrm{ECQ}$ for output $Q_{t} Q$ actually paid out $Q_{t} H C Q$. The difference, HEC, represents a loss to consumers due to the reduced volume of consumption. ${ }^{23}$

4. Consumption tax effect. The cost of import good consumption (regardless of the supply source) increases in the amount $\left(P_{t}-P\right)\left(O Q_{t}\right)=\operatorname{PHEP}_{t}$.

5. Tariff revenue effect. Tariff revenue collections from domestic consumers amount to $\left(\mathrm{P}_{\mathrm{t}}-\mathrm{P}\right)(\mathrm{FQ})=\mathrm{DEHG}$. This is a redistribution of income from consumers to government. No welfare cost is attached to the transfer since, by assumption, government either redistributes the revenues to consumers or spends the revenues as the private sector would.

6. Balance of payments effect. Import volume falls in the amount $B F+Q, Q$ (increased domestic production plus reduced total consumption) so that the deficit ledger of the trade account falls by $\left(B F+Q_{t} Q\right)(O P)=B A G F+Q_{t} H C Q$.

7. Welfare (real income) effect. The net effect is the sum of the gains to producers and government and the losses to consumers. This is $(2)+(5)-(3)-(4)=\mathrm{ADG}+$ HEC. HEC has already been described as a deadweight loss due to reduced import volume. ADG represents a deadweight loss in efficiency because the tariff induces a movement of factors from a more productive to a less productive use. It follows that, although the effect of the tariff on real income is negative, the tariff induces factor movement into import and importcompeting production, increases production of these goods, provides government with revenue, improves the payments balance, and redistributes income to producers and government. Consumers could bribe all the other economic agents (by

23. The measure of effect on consumers is usually termed consumer's surplus. The derivation of the measure involves the restrictive assumption that the measurement good display a zero income elasticity of demand. 
providing them with an amount equal to their tariff-induced gains) to prevent the tariff imposition, ${ }^{24}$ and thereby avoid the net loss. ${ }^{25}$

\section{B. Tariffs as a Correction for Market Failure}

The argument that tariff imposition corrects market failures is based on the notion that free trade sometimes fails to allocate resources efficiently so that some government intervention may increase efficiency. Conventionally, market failure arguments include the effects of externalities, the structure of the developing economy, and the infant industry case.

The infant industry argument has been frequently used to justify tariff imposition. It is based on the premise that a newly organized industry is relatively inefficient and that tariff protection permits it to become relatively efficient. ${ }^{26}$ It is commonly argued that the change in relative efficiency results from learning by doing and from the realization of economies of scale. In the real world, three major application problems may preclude these results: (1) it may be difficult to identify an infant industry which could eventually acquire a comparative advantage, (2) it may be very difficult to determine when and if the tariff should be abolished because prices tend to be inflexible downward so that any cost reductions provide larger returns to productive factors and vested interests, and (3) the case for protection requires a difficult comparison of discounted costs of protection against benefits over typically different time dimensions. Also, a strong counterargument is presented by the Coase theorem, which suggests that social and business organizations adjust to internalize externalities. ${ }^{27}$

An externality-induced market failure occurs whenever activities by consumption or production agents affect third parties through mechanisms other than price (e.g., alterations in technological or consumption opportunities). The externality may have positive or negative effects. Common examples include pollution, urbanization, national defense capacity, and immiserizing growth. The Coase theorem posits that the externality exists because some property right has not been assigned; therefore, there is no incentive for the externality generator to consider it in the decision calculus. Any assignment of the property right would force its inclusion in the decision calculus and preclude the market failure. ${ }^{28}$ Nevertheless, such a market solution may be precluded because negotiation costs are greater than the value of the externality or because social organizations cannot or will not assign certain property rights. Under these circumstances, positive externalities may be encouraged by an increase (or negative externalities discouraged by a re-

24. This possibility is one explanation for the view that the tariff is an inefficient way to accomplish these results.

25. This model contains no terms of trade effect, so the tariff-imposing nation cannot use the policy to raise its real income.

26. The same argument has been applied to industries operating with inefficient and obsolete equipment and techniques.

27. An explanation of this argument follows in the section on the externality market failure argument. See Coase, The Problem of Social Cost, 3 J. L. \& ECON. 1 (1960).

28. The assignment forces, for example, the generator of a negative externality to include as a cost any payment that those adversely affected might pay to prevent the activity. 
duction) in the relative price of the good in question. Tariffs are a device to accomplish this change in relative prices.

The developing economy structure argument arises from the observation that some predominantly agricultural developing economies have very low average product values for agricultural labor. This suggests that the marginal product for labor is very low. These same economies have relatively weak industrial sectors which, nevertheless, set wages for the agricultural sector. These wages are too high to permit profit maximization in agriculture. Put differently, the agricultural sector has surplus labor. ${ }^{29}$ Accordingly, protection of the industrial sector would induce greater output and draw labor from the agricultural sector into the industrial sector. The average product of labor would rise, providing an improvement in national welfare.

\section{Tariffs to Attain Income Redistribution and Other Social Goals}

Social welfare objectives typically include income redistribution, revenue generation, and industrialization. The income redistribution question was evaluated, in part, in the partial equilibrium setting above. There, income was redistributed from consumers to producers and to government. However, the partial equilibrium model is predicated upon no changes in other markets. Therefore, the factor bills increased but the actual level of wages and rents remained the same. The only effect was to increase the firm's profits. ${ }^{30}$ Accordingly, an analysis of the effect of an import tariff on wages and rents requires a general equilibrium analysis. ${ }^{31}$ The effect of terms of trade changes upon wages and rents has been evaluated in the neoclassical trade model proposed by Hecksher and Ohlin. ${ }^{32}$

\section{III}

\section{The Second Best Argument Against Tariffs}

The issue is the efficiency with which import tariff strategies can accomplish economic and noneconomic objectives. In this sense the tariff is often second best. ${ }^{33}$ The general result is that the import tariff is a relatively efficient technique to maximize real income in the presence of trade monopoly power and to reach trade level objectives. This strategy is relatively inefficient in reaching other goals.

Recall Figure 1 and its assumptions, as well as the effect of the import tariff on consumption, production, and income distribution. ${ }^{34}$ Assume a national objective

29. This argument has not been empirically proven or disproven.

30. The perfectly competitive firm, in equilibrium, produces where profits are zero (every factor paid at least as well as in the next best alternative). The area under the supply schedule covers variable costs; the so-called producers' surplus covers fixed costs. The price increase due to the tariff enlarges the producers' surplus. However, fixed costs do not change. Consequently, there are extra revenues to be retained by the firms or distributed to owners.

31. This analysis is general in the sense that no markets are assumed to be insulated from changes in other markets. This permits evaluation of changes in the terms of trade.

32. See B. Ohlin, Inter regional and International Trade (1933). See also Kreinin, North American Economic Inlegration, 44:3 LAW \& CONTEMP. PrOB. 7 (1981).

33. Second best has several meanings in economics. Here it is used to denote less efficient. Later it will be used to identify an optimum solution when free trade cannot be obtained.

34. Recall also that this case assumes no terms of trade effect. 
of domestic production of imports and import-competing goods of amount OF. ${ }^{35}$ This production target comes at a national cost of ADG + HEC. The consumption loss, HEC, could have been avoided. ${ }^{36}$ The same output target could have been reached by a free trade policy (implying a price of $O P$ and consumption in amount $O Q$ and a subsidy of DG per unit of output. The subsidy has the effect of shifting the domestic supply schedule downward to $S_{s}$ while producing the free trade consumption solution. As a result, consumers avoid the consumption tax and consumption effect and benefit by PCEP $_{t}$. Government loses revenue in amount $D E H G$, and there is a subsidy cost of $(D G)(O F)=$ PGDP $_{t}$. The net savings in attaining the production constraint by subsidy rather than by import tariff is HEC. Plainly, the import tariff strategy is second best because the subsidy does not change the price and, therefore, does not create a consumption distortion. ${ }^{37}$

This same analysis can be applied to evaluate noneconomic consumption targets. Using Figure 1 and its associated assumptions, assume a consumption target of $O Q_{\mathbf{t}}$ units of the import. The import tariff achieves this result at a cost of ADG + HEC plus resource reallocation costs. A direct consumption tax on imports would shift the demand schedule to $D_{t}$. This produces the desired consumption effect without creating a production distortion, and reduces the cost of the policy to HEC. Once again, the tariff is second best to a more direct policy. ${ }^{38}$

Finally, an intention to redistribute incomes to rectify some noneconomic factor payment differentials can be best accomplished by a factor tax or subsidy. The tariff strategy falls into the second best range. ${ }^{39}$ Moreover, these policy prescriptions are equally applicable to the cases of distortions originating in the market. Distortions originating in the market have the same effect as noneconomic distortions in that they prevent the satisfaction of Pareto optimality conditions. ${ }^{40}$ For example, a noneconomic production target below the level where price equals marginal cost (the efficient production optimality condition) or simply where demand equals supply in competitive markets forces price to exceed marginal cost.

35. Bhagwati calls such constraints noneconomic. See Bhagwati, The Generalized Theory of Distortions and Welfare, in Trade, Balance or Payments and Growth 87 (1971).

36. A target of reduced production could be efficiently obtained by a production tax.

37. This conclusion may not be appropriate for a nation which can affect the terms of trade by its tariff policy. Such an economy may minimize the cost of such noneconomic constraints by imposing a combination tariff and tax/subsidy policy. More specifically, such an economy should impose the optimum tariff and then use a tax/subsidy to discourage/encourage production to reach a target level different from that induced by the optimum tariff. The common sense of this is that the optimum tariff maximizes real income and raises it to a level above that reached in free trade, so that any further price adjustment by tariff rate changes may allow satisfaction of the production target but injures consumers. Hence, the consumption distortion may be avoided by an appropriate production tax/subsidy. Alternatively, the tariff rate should be used so long as the production and consumption effects are not negative; once this point is reached, the policy choice should be as in the text.

38. An objective of increased consumption could be appropriately reached by a consumption subsidy.

39. This conclusion will be modified in an economy having international monopoly power.

40. The Pareto optimality conditions are that the domestic marginal rate of trasformation (or relative marginal costs of production) equals the foreign marginal rate of transformation (or world relative prices) which equals the domestic marginal rate of substitution (or the relative value of goods to consumers). These conditions ensure production efficiency and consumption efficiency or simply that no reallocation of products or factors (given the orignal allocation) can be made such that one party gains and no other party loses. The main theorem of trade is that these conditions are satisfied by free trade in perfectly competitive markets. 
This distortion, by the foregoing analysis, can be achieved at least cost by a production tax. Now, suppose that no target exists but that the market for this product is characterized by monopoly. ${ }^{41}$ Monopolists maximize profits by producing where price exceeds marginal cost. This distortion is analytically equivalent to the preceding one and can best be removed by a production subsidy. ${ }^{42}$

This general conclusion has been termed the specificity rule. ${ }^{43}$ It means that distortions ought to be eliminated or created by intervention directed specifically to the particular distortion. Hence, tariff imposition when there is no international monopoly power is an inefficient device to attain a nontrade level objective (e.g., a preference for industrialization or income redistribution within an economy).

\section{IV \\ Conventional Customs Union Theory}

As described earlier, the essence of integration and of customs unions in particular is geographically discriminatory trade preferences. The customs union formation involves tariff elimination between members and a common external tariff against nonmembers. The early analyses of the customs union formation were unpublished because the results were deemed to be trivial; it seemed obvious that the reduction in some tariff levels without changes in others was a movement toward freer trade and therefore desirable. This generalization was first identified as incorrect by Jacob Viner. ${ }^{44}$ Viner's analysis, ${ }^{45}$ which focused only on production and not on consumption, demonstrated that union formation may increase rather than reduce production inefficiency by relocating production in a member nation unable to compete on the world market without protection. Essentially, this is an application of the second best analysis in the previous section. The different national tariffs prevent Pareto optimality; removal of some, but not all, of these distortions may or may not be welfare increasing. ${ }^{46}$ Alternatively, given the distortion (an import tariff), the second best optimum may not involve tariff preferences granted to a subset of trading partners. ${ }^{47}$

41. This discussion presumes that the nation has no international monopoly power.

42. A tax in the amount of monopoly profits would make the monopolist indifferent between that output and a larger one.

The symmetry in these analyses is striking. One problem concerns the creation of a distortion while the other concerns its removal. The former may involve movement from Pareto optimality, the latter involves movement to Pareto optimality. The ranking of policy choices for each problem by least cost is the same because the problems are duals. Further, it matters not whether the distortion is due to imperfect markets (e.g., increasing returns to scale) or results from a policy directed elsewhere or is the intended result. All fall into the same class of problems. See Bhagwati, supra note 35 . Alternatively, the noneconomic constraint variant suggests that the eventual equilibrium is second best to free trade and provides conditions to attain a second best optimum. The economic constraint variant suggests a second best solution which is not a second best optimum and specifies the conditions to attain the latter.

43. C. Kindleberger \& P. Lindert, INTERnATIONAL ECONOMiCS 136 (6th ed. 1978)

44. J. Viner, The Customs Union ISSUe (1950).

45. Note that the issue of international monopoly power is again decisive for the analysis.

46. Bhagwati, supra note 35. See also, Lancaster \& Lipsey, The General Theory of Second Best, 24 REV. ECON. STUd. 11, 14 (1950).

47. Ozga has shown that it may not even involve the granting of preferences to all trading partners. Hence, unilateral tariff reductions may not be welfare or real income enhancing. See Ozga, An Essay in the Theory of Tariffs, 63 J. Pol. ECON. 489 (1955). 
The Vinerian production effect and the distinction between trade creation and trade diversion can be illustrated simply. Assume the nation joining a union has no international monopoly power and consumes products in fixed proportion (meaning that consumption bundle composition does not change with relative price changes). Using Figure 2, identify OA as the fixed proportion consumption curve and $\mathrm{BC}$ as the constraint on consumption at world prices. ${ }^{48}$ Let this world price be determined by the low cost producer. Then equilibrium occurs at point $D$. Let the nation form a union with a higher cost producer. Then, although output of this nation's export is unchanged, the equivalent consumption constraint will be smaller. Let this new constraint be $B E$ with an equilibrium at point $F$. Plainly, this nation now consumes less of both goods (between points $D$ and $F$ ) and has lost real income. Trade has been shifted from a lower to a higher real cost source. This shift is termed trade diversion and reduces real income.

Analogously, trade creation involves a production relocation from a higher real cost source to a lower real cost source. This would increase real income by moving production to a more efficient location. Using Figure 2,49 assume that a nation has a prohibitive import tariff in place blocking out all imports regardless of source, and now produces at point $\mathrm{F}$ on $\mathrm{BE}$. (It must be $\mathrm{BE}$ rather than $\mathrm{BC}$ since the former represents a higher relative price (cost) for imports). Then, customs union formation with any more efficient producer allows a real income gain (e.g., a shift from point $\mathrm{F}$ to point $\mathrm{D}$ ). This analysis led Viner to conclude that trade diversion was necessarily real income or welfare reducing and that trade creation was wel-

FIGURE 2

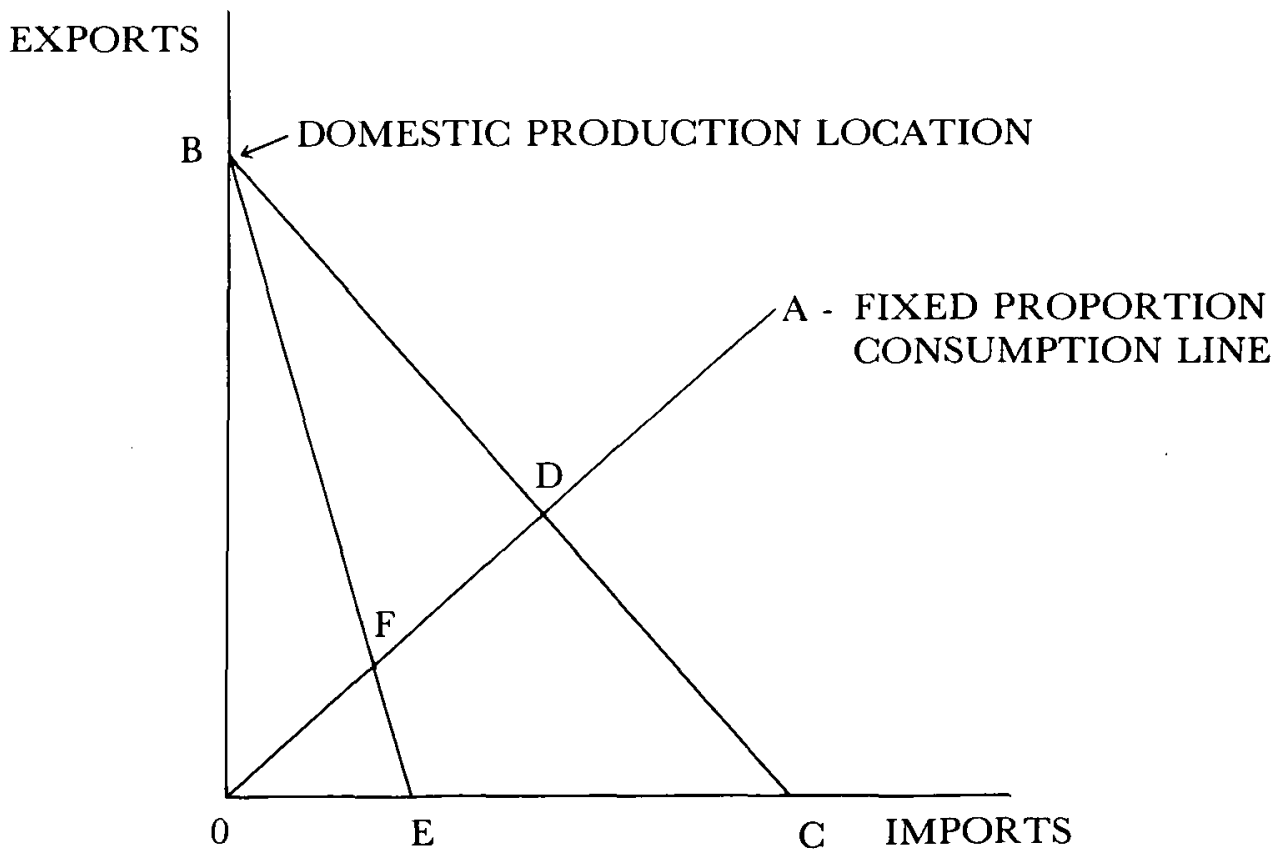

48. Assume tariff revenues are redistributed to consumers so that the tariff affects only relative prices and not nominal income.

49. A similar figure was initially used by Lipsey, supra note 2, at 500 . 
fare increasing. As a result, Viner proposed a comparison of production conditions in potential member nations as a guide to which effect (creation or diversion) would likely dominate..$^{50}$

The weakness of Viner's analysis was the assumption that consumption proportions were independent of relative prices. Later analysis by Meade and others included relaxation of that assumption in order to permit consumption good substitution. ${ }^{51}$ Generally, the union formation reduces the relative price of the tariff-ridden good and encourages its consumption, thereby increasing imports from partner nations, reducing imports from nonunion members, and reducing consumption of other domestically-produced products. This has important effects on real income which may counter any trade diversion losses. Consider Figure 3 and assume that production occurs at point $A$ and consumption at point $B$ where an indifference curve ${ }^{52}$ is tangential to the consumption opportunity constraint, AC. ${ }^{53}$ The slope of $\mathrm{AC}$ is the terms of trade.

FIGURE 3

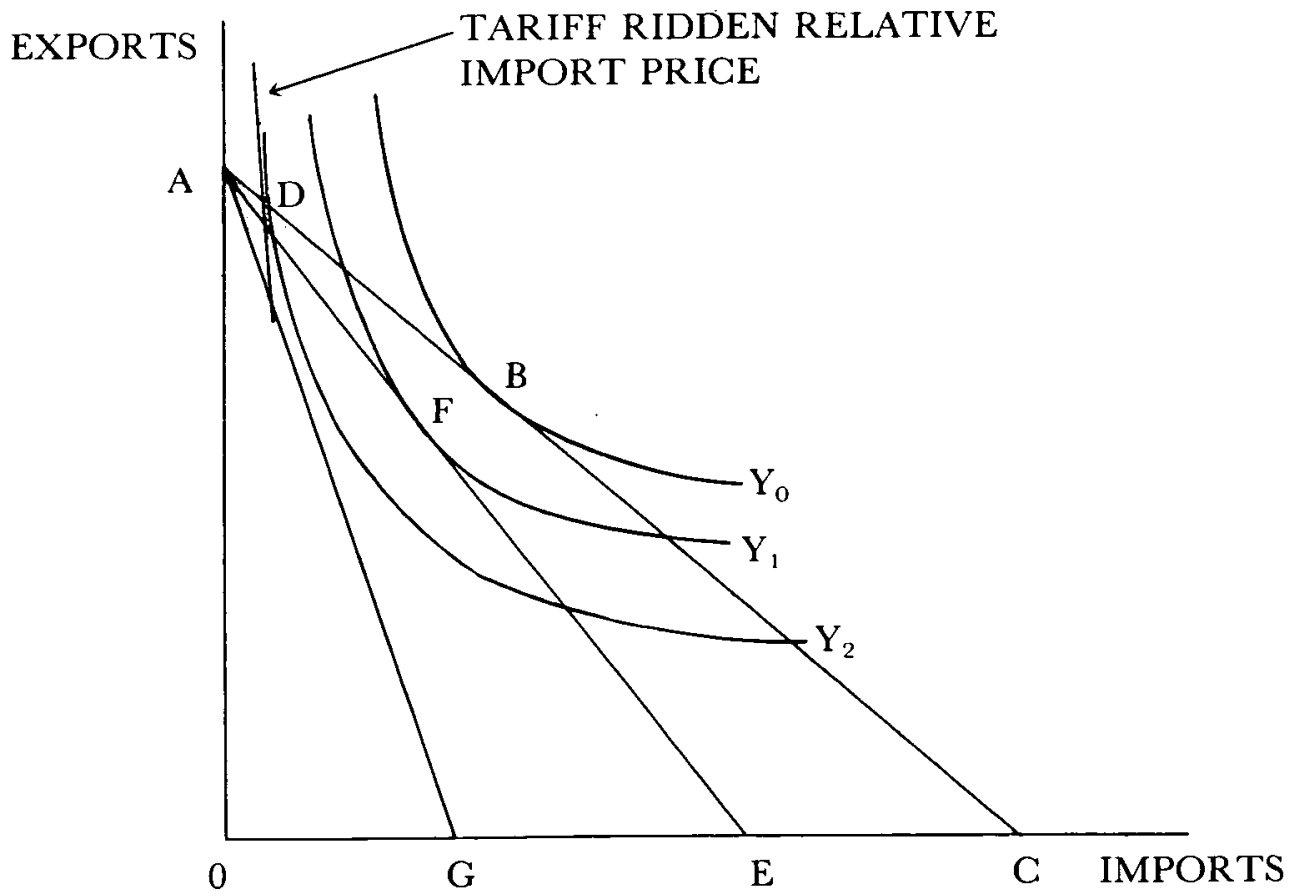

50. J. VINER, supra note 44. This will be considered below. The general result is that trade creation is likely if production patterns of protected goods are not complementary between union members and if the cost patterns are different.

51. See, e.g., J. Meade, The Theory of Customs Unions (1956).

52. The indifference curve indicates alternative consumption combinations which equally satisfy consumers. The further the indifference curve from the origin, the greater the associated real income.

53. This figure was first presented in Gehrels, Customs Unions from a Single Country Viewpoint, 24 REv. ECON. STUD. 61, 62 (1956-57). 
Then, apply an import tariff which does not affect the terms of trade. The new equilibrium must occur on $\mathrm{AC}$ (which defines the real value of production on world markets) at a point where the domestic relative price of imports is tangential to an indifference curve. Since the tariff drives up the relative price of imports, the new equilibrium must occur near point $D$. Real income has fallen due to the tariff. Now suppose that union formation would allow trade at a relative price consistent with the slope of $\mathrm{AE}$. The new equilibrium occurs at point $\mathrm{F}$ which is preferable to point D. ${ }^{54}$ This is so even though union formation entails trade diversion (here $\mathrm{AE}$ represents a greater real relative cost than does $\mathrm{AC}$ ). The common sense explanation for this result, which contradicts Viner's conclusion, is that the production effect moves the existing level of import production to a higher cost source while the consumption effect entails substitution of lower priced units from the partner for higher priced units from outside the union. A more complete analysis should recognize that the consumption effect also induces a production response in the import sector. Specifically, the consumption effect increases the level of imports by the mechanism above and by discouraging domestic import and import-competing production of those goods. The latter adds to the gains from trade. 55

The generalizations describing the likelihood of a nation's gain from customs union formation are: (1) gain is more likely the more competitive the prospective member economies are in the markets of protected goods; (2) gain will be larger the more dissimilar the relative prices of protected products in the member economies and the more similar these relative prices in other economies; (3) given a nation's trade volume, gain will likely be greater the higher the proportion of this trade volume attributed to prospective union members; 56 (4) gain will likely be larger the greater the initial tariff barrier; (5) gain will likely be larger the smaller the common external tariff; and (6) gain will be larger when the products of prospective member nations and other nations are less substitutable. ${ }^{57}$

The explanations for these generalizations utilize arguments incorporated in the text. Generalization (1) reflects the greater potential for trade creation which exists when member economies display similar production lines before union formation. Similarly, the first consideration in generalization (2) focuses upon conditions enlarging trade creation gains while the second element focuses upon conditions reducing trade diversion losses. Generalization (3) focuses upon condi-

54. Real income need not rise with union formation. For example, a union price ratio of AG would produce a net loss.

55. Lipsey has incorporated this analysis in the terms intercountry substitution and intercommodity substitution. This is important simply because it suggests the low-high cost location problem and recognizes that consumers adjust purchases according to relative prices so as to maximize real income. A simple example-the price of a good falls and it is substituted for other goods because, by doing so, consumers maximize their satisfaction from consumption. Put differently, consumers adjust consumption to maximize real income. Here, consumers are able to reorganize consumption because the price they face for import goods falls with union formation. See Lipsey, supra note 2, at 504 . It is useful to note that the partial equilibrium analysis in the text showed a production loss of ADG due to the tariff (Figure 1). The intercommodity substitution reflects changes in relative prices which also serve to alter production. Here, the gain will be something less that ADG.

56. Lipsey, supra note 2, at $\mathbf{5 0 8}$. Terms of trade are not considered.

57. Some of these generalizations were first suggested by J. MEADE, supra note 51, at 107-11. 
tions which reduce the probability of trade diversion losses (e.g., there can be no trade diversion when the customs union involves all actual and potential trading partners). Generalizations (4) and (5) stress conditions which enlarge trade creation gains and reduce trade diversion losses, respectively. Finally, generalization (6) identifies a condition affecting the degree of trade diversion losses.

The preceeding analysis assumed that customs union formation did not affect the terms of trade. This assumption is valid in only a limited number of cases. ${ }^{58}$ An important series of questions concerns the effect of union formation on the intraunion terms of trade and the terms of trade between each union member and the rest of the world. Unfortunately, there are no unambiguous results or simple generalizations, but several points can be made. As discussed earlier, the balance of trade reflects market forces operating on internationally traded goods and a balance of these forces yields an equilibrium terms of trade. This equilibrium terms of trade may be adjusted by customs union formation. Trade diversion due to customs union formation reduces the volume of imports from outside the union so that the equilibrium terms of trade (for any surviving trade) for the importing union member vis-á-vis the rest of the world must improve. ${ }^{59}$ Consequently, there is an increase in that nation's real income from that trade with the rest of the world which survives union formation. This gain counters trade diversion losses and invites attempts to exploit the rest of the world by some union tariff policy. ${ }^{60}$ Quite plainly, this result and the previous conclusions concerning customs union formation may hold for each union member. This result makes clear the error in the view that customs union formation aids the exporting union member at the cost of the rest of the world. The costs of diversion are actually borne by consumers in the importing union member (with possible mitigation by a terms of trade improvement). The intraunion terms of trade effect is similarly considered. The trade diverted to union members and intercommodity substitution forces the importing members' trade balance into deficit. Correction requires a terms of trade deterioration (improvement for the exporting union member). ${ }^{61}$ In essence, this forces up the cost of these imports so that trade diversion is more costly when the exporting union member's export supply schedule reflects increasing (rather than constant) costs. However, part of this loss is an intraunion transfer to export good producers. Overall, the impact of union formation upon the intraunion terms of trade is difficult to predict because these effects could occur in all union members simultaneously. ${ }^{62}$

58. These limited cases are those of the small nations which have no international price setting capability.

59. The common sense of this is that the reduction in demand for imports faced by the rest of the world forces a movement down the supply schedule of the rest of the world, thereby lowering the absolute and relative price of the import good. The critical assumption is that the supply schedule considered above is no longer horizontal.

60. It is useful to recognize that real income is the decision variable here.

61. See H. Johnson, Money, Trade And Economic Growth at 56-57 (1967). As Johnson pointed out, a terms of trade gain is more likely to occur the more inelastic is the supply of exports schedule from the rest of the world. Additionally, the cost of trade diversion (over the constant cost case) falls as the exporting union member's export supply schedule becomes more elastic.

62. This issue is nevertheless broached in rough form by the question of "balance" negotiation in the 
The difficulty in making unambiguous terms of trade predictions for customs union formation has forced attention onto other economic aspects of union formation. These are usually termed dynamic effects and include the effects of: (1) increased competition among industries within the union; (2) an enlarged market which may permit economies of scale and generate higher average rates of growth; and (3) expanded capital inflows to the union. The increased competition argument is that tariff elimination among members eliminates a source of monopoly power and allows exposure of formerly protected firms to other competitors. The expected result is increased efficiency. The liability here is obvious-the inefficient firms may be driven out of the market, leaving the possibility of the reestablishment of monopoly power. A customs union enlarges the market available to any producer located within the union. This tends to encourage further specialization in production and thereby cost reductions. These economies of scale can result, for example, from learning by doing or the establishment of a skilled factor pool. Scale economies might also result from increased competition which tends to reduce monopoly and imperfect competition. These imperfect market structures tend to result in differentiated products and correspondingly shorter production runs. Increased competition tends to increase the length of production runs by reducing the number of differentiated products. This increased intraindustry specialization may also result from the supplantation of differentiated products satisfying particular custom union member nation preferences by similar products produced elsewhere in the union. ${ }^{63}$ Average growth rate increases result when the enlarged market effectively reduces the risks of expansion and/or innovative investment and encourages firms to take advantage of opportunities to expand their relative and absolute shares of the market. ${ }^{64}$ Finally, the prospect of a common external tariff may encourage an inflow of foreign capital so that the capital owners can produce and compete within the union without the tariff burden attached to union imports. This result benefits the union. ${ }^{65}$

union formation process. See P. Robson, Current Problems of Economic Integration, at ch. 3 (1971).

63. It has been shown that Canada did not realize scale economies relative to the U.S. because the Canadian output mix was highly differentiated. See Daly, Scale and Specialization in Canadian Manufacturing (Economic Council of Canada Staff Study No. 21, 1962). Grubel found that trade growth among EEC members took the predominant form of increased intraindustry trade. See Grubel, Intra-Industry Specialization and the Patlem of Trade, 33 CAN. J. ECON. \& POL. SCI. 374, 376-80 (1967).

64. See T. Scitovsky, Economic Theory and Western European InTecration, at chs. 1,3 (1958). The enlarged market should also induce future enlargements due to income growth. For example, trade will continue to be needed as income grows for products which are income elastic (so that, for example, a 5 percent increase in income leads to 10 percent increase in expenditure on that good).

65. Mordechai Kreinin has pointed out that the view that these growth implications of customs union formation are usually presented as real income increasing to the rest of the world is incomplete. He argued that the immediate effect of union formation is to reduce growth rates in the rest of the world by trade diversion and terms of trade losses (or simply market reduction) and investment diversion. As a result, the "dynamic consolation prize usually offered to non-participating nations . . . is not always valid." See Kreinin, On the Dynamic Effects of a Customs Union, 72 J. Pol. ECON. 193, 195 (1964). Consequently, retaliation to union formation has its attractions. Additionally, member nations may have objections to foreign ownership and, therefore, seek to create disincentives for this inflow. 


\section{$\mathrm{V}$ \\ Criticism and Extension of Conventional Customs \\ UNION THEORY}

The major criticism of the customs union analysis presented above is that, abstracting from terms of trade effects and dynamic considerations, some nonpreferential tariff structure can generate the same results at lower cost. ${ }^{66}$ The essence of this conclusion can be seen in Figure 4 below. The domestic demand and supply schedules for imports are given by $\mathrm{D}$ and $\mathrm{S}$, respectively. The import supply schedule for the prospective union is given by $\mathrm{SHS}_{\mathrm{u}}$ (reflecting the prospective partner's ability to produce at lower cost than the domestic economy for outputs greater than that at point $\mathrm{H}$ ). The world import supply schedule is given by $\mathrm{S}^{*}$ and is horizontal so that no terms of trade effect can occur. Plainly, the world supply price is less than that of the prospective partner economy. Assume that the domestic nation imposes a nonpreferential tariff rate of $t$. This forces the world supply schedule to $S^{*}$, with $A B / O B$ representing the tariff rate. The uniform application of this rate makes trade with the rest of the world more attractive than with the prospective partner. The effective import supply schedule becomes $\mathrm{SHJS}^{*}$. The equilibrium solution occurs at point $\mathrm{K}$ with domestic production of import and import-competing goods in amount $\mathrm{OE}$, domestic consumption in amount $\mathrm{OF}$, and imports in amount EF. These imports are taken from the lowest real cost external source.

\section{FIGURE 4}

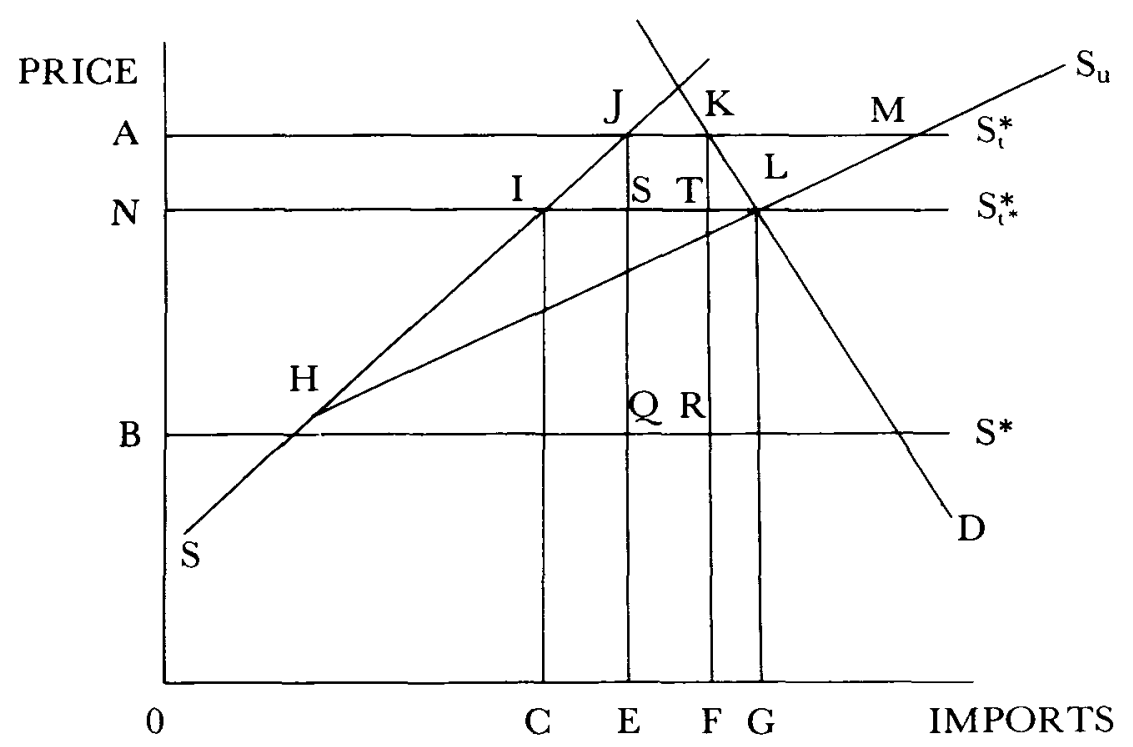

Assume a customs union is formed with the result that the tariff rate $t$ is main-

66. This argument is made in Cooper \& Massell, A New Look at Customs Union Theory, 75 ECON. J. 742 (1965). 
tained on world supplies of the import good and eliminated on imports from the partner economy. The effective import supply schedule becomes SHLMS*, with equilibrium occurring at point L. Consequently, domestic production declines to the amount $\mathrm{OC}$ and consumption increases to the amount $\mathrm{OG}$. Accordingly, imports rise to amount CG where EF reflects trade diversion (imports taken from a higher real cost location), CE represents trade creation (production relocation to a lower real cost location as part of intercommodity substitution) and FG represents trade creation due to consumer substitution of imports for other products which are now relatively more expensive. In summary, consumers gain in surplus by AKLN, domestic producers lose an effective subsidy of AJIN, and government loses tariff revenue in amount JKRQ. The latter loss is attributable solely to trade diversion. On balance, the net effect on real income is JIS + KLT - STRQ. This result may be positive or negative (the geometry shows it as a loss here). The point of this criticism can be seen by the imposition of a nonpreferential tariff rate of $\mathrm{BN} / \mathrm{OB}$ or $\mathrm{t}^{*}$ on $\mathrm{S}^{*}$. Then, the effective supply schedule becomes SHILS ${ }_{\mathrm{t}^{*}}$ which yields the same production and consumption results as the union case. However, the trade diversion loss of STRQ is avoided because tariff revenues are still collected. ${ }^{67}$ Accordingly, an appropriate nonpreferential tariff policy appears preferable to the customs union because it avoids the trade diversion loss. This raises the question why customs unions are ever preferred to a nonpreferential tariff policy. ${ }^{68}$ Further reflection leads one to question why protection is ever adopted over free trade when these alternatives are evaluated using the real income standard. ${ }^{69}$

The proposed solutions to these questions have included: (1) a respecification of the decision objective function to include political or collective objectives absent in the traditional analysis (e.g. , a collective preference for industrial development); (2) recognition of the appropriateness of tariff strategies to exploit monopoly/monopsony power and to attain trade balance objectives (balance of payments targets in a world of fixed or quasi-fixed exchange rates and given terms of trade); and (3) explicit acceptance of the hypothesis that dynamic considerations overwhelm the static effects.

The collective objective argument is important and useful in explaining real world events. The argument is that real income consists of private sector consumption of real goods and services (as before) and collective or public consumption of government-provided real goods and services. The objective remains to maximize real income with the recognition that additional collective consumption requires a reduction in private consumption. Accordingly, society may maximize real income by imposing a tariff which encourages the collective consumption of indus-

67. An alternative is to recognize that this policy permits the purchase of inputs at a lower real cost. It has been observed that tariff revenues lost in union formation must be provided in a less efficient way if the services financed by the tariff are not to be lost. Id. at 746 .

68. The optimum tariff argument is ruled out by assumption. Also, the second best arguments mean that tariffs are inefficient in certain instances.

69. An analogous question recognized by Johnson is why tariff negotiators regard tariff reductions as concessions requiring compensation if tariff reductions are generally beneficial (recall Ozga's contrary result). See Johnson, An Economic Theory of Protectionism, Tariff Bargaining and the Formation of Customs Unions, 73 J. POL. ECON. 256 (1965). 
trial production at a cost of reduced real private consumption. ${ }^{70}$ As the previous discussion suggests, such industrial production could be achieved at lesser cost by a subsidy program. Nevertheless, tariff policies are generally used because: (1) the revenue required to cover subsidy payments may be difficult to collect; (2) the tariff policy permits the domestic industry to appear competitive; and (3) GATT principles forbid direct export subsidization. ${ }^{71}$

The equilibrium conditions can be developed easily. Expanded real income will be maximized when the marginal private cost of protected industrial production equals the marginal collective value of such production. ${ }^{72}$ The marginal private cost may be divided into a consumption cost and a production cost. The latter is the degree of tariff protection-the wedge between world and domestic production costs. The consumption cost is the real income loss resulting from the tariff-induced price increase. As a result, the marginal private cost of protected industrial production schedule (hereinafter marginal private cost) lies above the product supply curve for the output levels which are only attainable with protec-

\section{FIGURE 5}

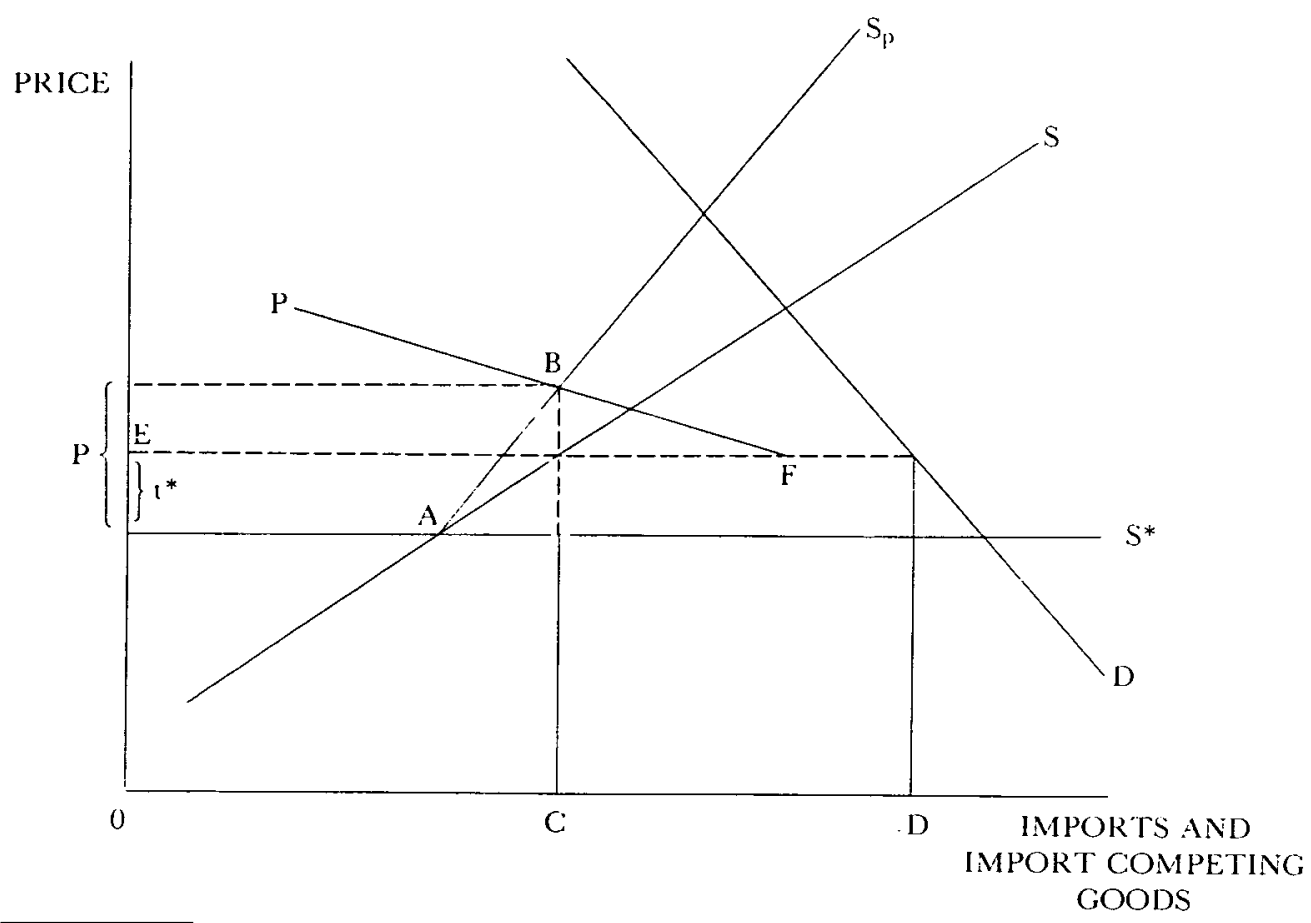

70. This is consistent with the development plans of many economies. This approach avoids the traditional result that the choice of protection is not economic and therefore irrational. Instead, it suggests that the degree of apparent irrationality is really a measure of the premium paid to attain the trade-off. See G. Becker, The ECONOMics OF Discrimination (1957).

71. The General Agreement on Tariffs and Trade (GATT) is an international institution designed to encourage multilateral tariff reduction negotiations and to formulate rules to prevent undesirable protectionism. These explanations and much of what follows draw upon Johnson, supra note 69 . Note also that most nations forbid foreigners to dump (sell below cost) in their markets for fear of eventual monopolization. Such a procedure could be a result of direct subsidy.

72. This is the Pareto Optimal Solution. 
tion. Using Figure 5, the domestic supply and demand schedules for imports are given by $\mathrm{S}$ and $\mathrm{D}$, respectively, and the world import supply schedule is given by $\mathrm{S}^{*}$. The marginal private cost schedule is given by $\mathrm{AS}_{\mathrm{p}}{ }^{73}$. The marginal collective value schedule is given by $\mathrm{PF}$. Equilibrium occurs where marginal private cost equals the marginal collective value at point $B$. Therefore, the approprite tariff rate to maximize expanded real is $t^{*}$. Domestic production occurs in amount $O C$, domestic consumption occurs in amount $O D$ with imports in amount CD. The tariff-ridden domestic price will be OE, or the world supply a price plus the tariff.

The degree of preference for industrial production is the premium paid to obtain it, p. This analysis suggests that the less competitive the domestic industry, the greater the likely degree of protection. (This means that point $\mathbf{A}$ in Figure 5 would be located further down the domestic supply schedule). Similarly, a deterioration in competitive capability (i.e., a shift to the left of supply schedule) would call forth additonal protection to maximize expanded real income. A prohibitive tariff precludes all imports, so that additional industrial protection can only be attained by subsidizing the production of exports. Such a policy must be accompanied by additional tariffs to prevent reimportation and to prevent import substitution for export consumption. However, since GATT rules forbid export subsidization, industrial exporters have no use for a tariff strategy unless they have monopoly/monopsony power. In this event, however, the tariff strategy is attractive to industrial importers and exporters.

Customs unions grant preferences or discriminatory reciprocal tariff reductions. The issue becomes the attractiveness of such propositions. The focal point of an answer must be the reason for tariff imposition. Assume that reciprocal tariff reductions are negotiated between an industrial importing nation and an industrial exporting nation so that the terms of trade remain constant and payments are balanced. Then, the industrial exporter increases both its exports and imports. Balanced trade expansion means that each extra import unit permits an additional export unit to which is attached a marginal collective value for industrial production; therefore, this nation's expanded real income rises because the marginal collective value of imports exceeds its private value. The industrial importer also experiences an increase in exports and imports. However, each extra import unit substitutes for domestic industrial output and induces a loss in collective value. The industrial importer has no incentive to engage in reciprocal tariff reductions unless its terms of trade improve as part of the bargain. Without monopoly power, this improvement can come about only through the generosity of the industrial exporter.

A more generally applicable model of the same construction assumes that all nations are both industrial importers and exporters, so that all nations want protection and can profit from reciprocal tariff reductions. Recognizing that direct

73. The marginal private cost schedule reflects the addition of the consumption cost of the tariff to the supply schedule. The production cost is included in the supply schedule. The common sense of the consumption cost is that it is the consumer's surplus lost on the units no longer imported or the addition to real income required to allow the original free trade level of imports. 
export subsidization is illegitimate, nations can satisy the industrial preference through protection of domestic producers of import-competing products. Under these conditions and absent trade monopoly/monopsony power, a reduction in a nation's import tariff increases its imports. Imports then substitute for domestically-produced import-competing goods so that collective value is lost. The other nation's import tariff reduction encourages export production and provides an increase in collective value and expanded real income. Accordingly, reciprocal tariff reductions are imperfectly compensatory. Expanded real income rises in each economy because there is no marginal private cost for additional export production while there is a marginal private cost for additional import production. Consequently, a given collective value can be acquired at lower cost by export good expansion than by changes in output of the import. This result depends on the impermissibility of export subsidization so that the subsidy rate is zero. Since the subsidy (or tariff) is the vertical distance between the supply schedule and the marginal private cost schedule, a zero value makes marginal private cost zero. Alternatively, the impossibility of export subsidization means that society is unwilling to give up any private consumption for additional export production while it must do so to obtain additional import production. It follows that tariff reduction will continue until one economy has no tariff left.

GATT rules specify that the most favored nation principle must apply to tariff negotiations unless a customs union or free trade area results. Therefore, union formation may be attractive because any trade diversion (intercountry substitution) resulting from the preferential tariff elimination permits the partner to expand its export production at the expense of the rest of the world rather than by reducing its own production of import substitutes. The cost to the preference grantor is the price (cost) differential between the partner and the rest of the world. On the trade creation side, preferential tariff elimination offers the partner the whole of enlarged imports, only part of which represents a reduction in import substitute production. The most favored nation principle provides the partner with a smaller export expansion. Overall, preferential tariff elimination reduces the cost to each partner of offering the other partner additional collective value. As a result, customs union formation may be a lower cost technique for satisfying the collective preference for industrialization. ${ }^{74}$ It is important to note that this extension of the customs union model has trade diversion as a positive welfare factor and that this result stems from the assumptions of a preference for industrialization and the impossibility of direct export subsidization. Consequently, the customs union alternative becomes more attractive as: (1) the industrial production preference becomes stronger (implying the collective value gains are relatively larger); (2) the nation's competitive position in industrial production becomes weaker (so that industrial exports are relatively small); (3) the comparative advantages (disadvantages) do not match between partners (representing a movement away from the rival economy conclusion of conventional analysis); (4) the member economies satisfy their collective preferences by import protection; and (5) the de-

74. The preference-receiving nation cannot benefit unless its export sales rise. Ergo, it must not sell more of its export to the partner before union formation than after it. 
grees of conditions (1) and (2) between potential partners are more similar. The latter reflects the fact that customs unions entail across-the-board tariff elimination so that each member wants to ensure that it will not be overly penalized for its partners' skills.

\section{VI \\ SUMMARY}

The main theorem of international economics is that free trade in perfectly competitive markets ensures production and consumption efficiency in each nation and for the world. Nevertheless, nations customarily impose tariffs to raise real income above the free trade level, to correct market failures, to redistribute income internally, and to facilitate industrial development. The frequent use of the tariff policies runs against the specificity theorem which states that the tariff is a relatively inefficient (in real income terms) policy for the attainment of most objectives.

The customs union was initially regarded as a movement toward free trade. Subsequent analyses have made it very clear that union formation may be either real income increasing or decreasing. The ultimate real income effect depends upon a balancing of the induced trade creation and trade diversion effects. These effects depend upon a large number of factors which cannot be generalized. Consequently, the magnitude of trade creation and of trade diversion cannot be predicted a priori. Therefore, static customs union theory provides no simple maxims and thereby accentuates dynamic considerations. 
